\title{
Russell to Lady Ottoline Morrell: the letters of transformation
}

$\mathbf{R}$ ussell's love affair with Lady 0ttoline Morrell, at its most serious in 1911 but shading into friendship after 1916, became an open secret in $i$ ts time. Thereafter the affair was all but forgotten in the annals of Russell's life. It is for us to rediscover Russell in that period through the large quantity of his surviving letters, together with her replies--an unequal but full correspondence. Ronald Clark in his Life of Bertrand Russezz shows the importance of these letters for understanding this most critical phase of Russell's development. ${ }^{1}$ As documentation the letters make credible Russell's change from a brilliant but limited mathematical logician into the fuller human being he became. We begin to understand the momentous personal transformation Russell underwent prior to World War I, which found him a pacifist, anguished by the suffering of all drawn into it. The letters to Lady 0ttoline could contribute greatly to a study of reasons for the strengthening of Russe1l's humane feeling, of his deepening realization of what it is to love and to suffer. We shall see this, but I want to look at the letters mainly as accomplishments in a literary form of which Russell became a master, a form for long an important branch of literature.

${ }^{1}$ Ronald W. Clark, The Life of Bertrand Russetl (London: Cape/ Weidenfeld \& Nicolson, 1975). See particularly the section called "The New Romantic". Russell says in his Autobiagrophy (Toronto: McClelland and Stewart, 1968), 11, p.15 that "The period from 1910 to 1914 was a time of transition. My life before 1910 and my life after 1914 were as sharply separated as Faust's life before and after he met Mephistopheles. 1 underwent a process of rejuvenation, inaugurated by ottoline Morrell and continued by the War." Russell al lowed that the affair with Lady Ottoline began in September of 1909; there is correspondence from March 1911, continuing in some fashion until her death in 1938.

In this paper the letters are cited by the number they bear, sometimes that of the Russell Archives while at others that given by their recipient, Lady $0 t$ toline, and by date when possible. Consecutive numbering is yet to be completed. 
As literary products the letters to Ottoline are often so brilliantly successful that simple appreciation of them is in order before debate goes ahead as to exactly what they explain about this and Russell's other amorous relationships. Becoming an ardent lover upon separation from his first wife Alys does not alone explain his ability to write with increased force and passion. That he was a philosopher of mathematics and 1 anguage helps to explain the precision and clarity with which Russell articulated the most involved emotional states he was to know upon leaving Alys. Yet even for a disappointed man at last finding new love, a man with the peerless intellectual equipment Russell possessed, these are extraordinary letters. At their best--and their level of excellence is consistently high, but especially in the opening years 1911 and 1912-they are the work of literary imagination at full stretch.

Russell valued acclaim as a writer not only of essays serving his rational and ironic side but of stories showing the imaginative also. The letters are certainly not fictional (though there is an element of make-believe in the love affair); nor are they mainly reasoned expressions of opinion about moral subjects as are many of the best essays. The letters are celebrations of Russell's personal release from the mental imprisonment erected by his own prior life and by philosophical work--a freeing into a realm opened to him by 0ttoline, temporary though the exultant freedom was to be. As celebrations of new-found passionate love, the letters take their place where imagination and reason intersect, joining the great statements of love in English letters, for example the poet Donne's verse letters to Lucy Countess of Bedford or even Keats' letters to Fanny Brawne. Ottoline herself was to realize this, writing, "It is a pity that so little of his imaginative side is known to people, or that it has been expressed, and for this reason I hope that his letters will one day be read." 2 Fusion of intellect with imagination during Russell's release into new freedom gives these letters distinction as literature. I want to say that, however unrealistic were Russell's hopes of transcendent religious truth to be found through love of ottoline, she inspired some of his finest spontaneous prose, by which his mind may be more surely known than by those writings with an immediate public purpose.

Before discussing an example from the heroic phase of their love, prior to complicating doubts, it may be said that Russell was very aware of the art he practised as a letter-writer. While attracted to such aggressively "modern" fiction writers as Lawrence and Conrad (both of whom figure prominently in the letters to Ottoline), Russell remained

${ }^{2}$ Lady Ottol ine Morrel1, Memoirs: A Study in Friendship 1873-1915, ed. Robert Gathorne-Hardy (New York: Knopf, 1964), p.285.
Victorian in his taste for clear but el egant statement. As was natural in the cultivated aristocratic Victorian society in which Russell grew up, the letter served both to convey necessary information and to give evidence of good breeding. A well-bred person was expected to be able to write good letters that said what they meant with a happy turn of phrase. As he wrote in the Preface to Dear Bertrand Russelz ... : A Selection of his Correspondence with the General Public (1969), "In my youth it was imperative to master the art of letter-writing if one was to make one's way in the world." While ridiculing the excesses of formality, Russell is quite definite in these remarks that letter-writing was a socially necessitated art, now regrettably lost.

Behind this again was the eighteenth-century epistolary vogue by which the reading public learned of the witty eloquence of, say, Horace Walpole or of the power to affect of William Cowper. By the nineteenth century, intellectual letter-writers such as J. S. Mill could also expect their correspondence to find its way to a considerable readership. Russe11, it appears, was an eager letter reader, though probably first attracted to Mill the person, his god-father, through the Autobiogrophy published in 1873 and then reintroduced to him when the letters appeared in 1910. Russell modified formal letter-writing of Mill's sort toward a penetrating self-analytical candour, an ability to govern and discuss while displaying the strong feelings that sometimes threatened to overwhelm him. To do this he must certainly have given thought to the letter as art--as a means of revealing and preserving in safety the emotional truth of his new relationship as it unfolded.

When Russei] came to prepare his Autobiogrophy for publication some years after drafting it, he included a variety of letters to convey the immediacy of situations noticed in the narrative, thus upholding the letter in its own right. It is remarkable much before, however, how many mentions there are in his corpus of the correspondences of others distinguished as letter-writers. Mentioned in the letters to Ottoline are letters by Keats, Shelley, Mme. du Deffand who corresponded with Walpole and voltaire, Dostoevsky, Tchaikovsky and Beethoven. These correspondences are frequently judged for their leavening effect on Russell's mind and are discussed along with other literature and art as agents of the metamorphosis he was undergoing. Having such a high standard made him critical of his earlier letter-writing and of the self it represented. He considers critically (in letter 529) his old letters returned by Alys, disliking the contemptuous tone they shared towards people in general and feeling himself to have been excessively critical of her. Russell knew that letters disclose the person at his or her most essential, and he wanted to be under no jllusions about the changes 
they represent. He reports reading through his mother's letters, given him by T. J. Cobden-Sanderson, looking for evidences of her character, a task in which 0ttoline participated. But most important are his comments on his own letters as literary efforts worth preserving. For example, in letter 322 he appeals to 0ttoline to "find any old letters of mine that seem to have bits that will do: I write better in letters, it seems to me." "Bits that will do", it appears, were choice prose extracts displaying his powers at their best on topics they had been discussing. Then or later ottoline set about marking what seemed the most impressive passages, such as the striking meditation on the River Thames in letter 87 . These markings show consistentiy good judgment, though as the affair's plot thickens the marked passages are the personal ones, not simply examples of literary excellence.

That Russell thought he wrote better in letters is an important comment at a time when he was searching for the best literary form for an expanding sensibility. Such a form apparently did not arise in the abortive piece on the philosophy of religion called "Prisons", nor did it satisfactorily appear in "The Perplexities of John Forstice", a modernized Platonic dialogue akin to Mallock's The New Republice and to G. Lowes Dickinson's A Moderm Symposium. It is in the letters, after a17, that Russell excels as a writer. But in spite of achieving the consummate form he frequentiy did, as I sha11 illustrate, Russel1 nonetheless seems to have thought that what he wrote in letters was more important than the letters as whole compositions. As this early stage he did not see that the excerpting technique might falsify the letters: total result as he came to seek it: an autobiography of an emergent self able to feel as acutely as he thought. It is doubtful that he ever realized the letters' full potential since in the 1930 s when preparing the Autobiogrophy he saw them in Ottoline's extracted form, not in their full painful array. This was in keeping with an earlier preference to think of developing particular topics in separate letters. He writes to Ottoline on 2 May 1912 (letter 435), "I should like to copy out everything in my letters to you that seems any good. Very likely that will suggest something else. I thought that what I wrote about beauty the other day was rather good."

The letters were returned and Russell went to work. Disillusioned with what he saw, he writes on 7 May 1912 (letter 441), "I have finished those letters--they are almost all worthless and had better be burnt. There is a great monotony about them." This judgment on himself is unduly harsh. The letters hold up in quality right through the war years, with Ottoline's opinion of them more reliable than his own. For example, she writes on 22 April 1911 that she is amazed reading his writing what extraordinary power and beauty of language it has, remarking on its passionate intensity as if "written with blood", to use Nietzsche's expression. Russell's poems, on the other hand, occasionally written into the letters and in which he placed more literary hope, show no such promise in beauty of language. "How wonderful it would be if I could really write poetry. It is not impossible I may be able to", he remarks on 11 May 1912 (letter 445). But the soaring imagination of Shelley, so long admired by Russell, was not his, nor could he attain the luminous profundities of Blake's verse, much discussed and appreciated by both Russe11 and Lady Ottoline throughout these letters. There is passion in Russell's poems to ottoline all right, but it is hobbled in comparison to that in the best prose in the letters themselves. Often he perfectly adjusts pace and tone to his meaning--the expression of religious awe in new love, the love that released Russell into a consciousness he thought impossible in the dreary years after his marriage to Alys went dead. Here in the letter of 9 January 1912 (311) is a sample of Russell to Ottoline at his most impassioned and imaginative, an exercise in self-transformation.

My Darling Darling I cannot tell you what a joy it was to me to find your dear dear letter when I got back. I feel every word of what you say with my whole soul. Yes it was more wonderful today than ever before - more divine and complete. I do feel something newthe absence of a barrier-a more perfect trust in each other and confidence about what is deepest. Yes, you have something of infinite value to give me- liberation and purification helping each other-and making me trust the moments of inspiration, which used to come very rarely and leave me doubting whether it was real inspiration or mere delusion. You have the vision more constantly and trust it more wholeheartedly than I have done. What I have had was hardly a visionrather the knowledge that there was a vision - a restless seeking and an infinite yearning - like trying to recover the almost faded memories of childhood - but always with the sense that nothing else really of childhood- - but always with the sense that nothing else really what I sought. And more and more you have given it to me. Now, at what I sought. And more and more you have given it to me. Now, at
times, especially when I am with you, I have the viston-but it is times, especially when I am with you, I have the vision - but it is yet express it. But that will come-its light will grow steadier and instant you reopened to me the whole world of beauty, and made me feel instant you reopened to me the whole world of beauty, and made me feel
again that it is worth while to live nobly. I had been so sensitive again that it is worth while to live nobly. I had been so sensitive
to inward discords and so rasped by their constant grating that no to inward discords and so rasped by their constant grating that no is no vision, nobility is a delusion, life is a mean petty thing, is no vision, nobility is a delusion, life is a mean petty thing, courage to live always with anguish, and perhaps they would be fools if they did. This is the truth-proclain it, live it, be sma11". But some strange pride, some instinct against giving in, sustained me, and I could not make myself small. Then, in a moment, when you came into my life, the whisper ceased, I found myself dizzy and bewildered, but seeing-knowing that it had been worth while to keep my soul alive through pain. I hardly know yet what it is that I have seen, but it is something of infinite importance. The first thing I saw was that frivolous living is of the Devil, that there is a noble life which 
can be lived, which ought to be lived whatever the pain it costs, and that it is only in a noble life that real beauty can find a home. Then I saw that love can redeem the noble life from the lonely aloofness which is its danger, and make it a life full of joy among common things. And now the great mystery of the world overwhelms me more and more- I feel I know so little, everything is so full of strange depths, inclich heights. In spite of the worship of reason. I have always utterly trusted inpulse and instinct and vision when I had thens it is when they have faded that I have doubted them But it is mysteriou to me why ave is bound up with them.

I feel tonight a great confidence in my powers of writing. The spiritual autobiography, like Sartor, seems to me rather a good form. It is so desirable to be able to make a dramatic statement of views one doesn't agree with and moods one has outgrown. And one can make the final outcome more complex and many-sided than in direct exposition. I have had many moods myself, and can imagine many others; they are useful as background to one's gospe1. Then there is more room for humour and irony and development; and one can be more tentative and undogmatic. All that we were saying in the train about the French Revolution finds no place in "prisons"-you felt that at the time, but $I$ was so occupied in keeping possessiveness in order that $I$ couldn't afford any wildness. Now that job is sufficiently accomplished and I am therefore freer - for the present. I believe any passion may be infinite if it has its root in Something universal- Swift's rage, for instance, is God-like, because it springs from the vision of wat forkind might be. But passion has insistence and religion has whe acquiescen. low are thesely instent, convered wants intense passion, intensely lnsistent, conquered sometimes by still more intense religion, but acquiescence ought to be difficult and rather rare if one is to have any force, don' $t$ you think so? What a marvellous thing life ls so full of strangeness and interest and wonder - passionate flaming souls set on this little planet, pouring forth their brightness into the vast interstellar night, infinite in. desire, godlike in understanding, utterly weak and helpless as regard their outward life, like a spark flickering in the winter wind. And here stand you and I - my thought has travelled through space and lived among the stars, it has gone backward in time to the dawn of Man, to the beginning of the world, it has loved and hated and fought - and all this pours itself out upon you - and grows greater in doing so. It is strange.

Goodnight my Life and my Light. I long for more and more wealth of heart and mind to give you greater and greater gifts with every day - Goodnight goodnight.

\section{You}

Russell rightly believed that Ottoline's attention to the arts (especially the visual arts) was far more finely attuned than his and that he stood to gain by refining his sensibility to match hers. He hoped to make good an unaccountable felt loss by attaining the "vision" to which this letter refers. Together they cultivated feeling through reading $\mathrm{Plato}$ and Spinoza, Vaughan and Blake, among other philosophers and poets, in search of the enlargement vision brings. It was a reaching forward into the realm of imagination drawn by the written word, but also it was a reaching back to "faded memories of childhood" as they exchanged experiences of loneliness. A mutual therapy, but with greatest need on Russell's side, was attempted with, he felt, success. Painting, music, prose from Charles Lamb to Tolstoy, and even to that of the intuitive moralist John Woolman, were discussed by these seeking people, for a time at least supporting each other in a mutual quest for meaning and beauty. Enhancing appreciation of each other through art and nature--long hours in the beech woods with reading aloud--they became "twin souls", attaining "sacred happiness", as 0ttoline put it early in the affair. Though no aesthete (never responding to Roger Fry's call to a new visual aestheticism), Russell was surprisingly amenable to 0ttoline's prescription for his soul's growth through the arts. He took her as a teacher and his capacity to feel noticeably enlarged, pushing to one side the restrictive "worship of reason" which he had come to see as a dangerous refuge. Better to worship beauty Russell seems to have decided, though this too would prove to be an extreme position not long occupied. That later in the correspondence Russell would retreat into the safety of "professional work", into what he called the transcendent purity of logic and a "hard intellectuality" to serve it, did not quite remove the gains in feeling made in the early phase of the affair with ottoline. The truth was that feeling became too much, she having become his sacred object, her beauty prompting him to long for the unobtainable beauty he called "mystical" in letter 153. A religious worship of eternal woman, transcending a mere personal relation, is implied throughout in the references to Dante, particularly after Russell began reading the Vita Nuova, as reported in letters of March, 1913 $(722,725)$. In the latter he calls these sonnets "quite supremely fine --the very highest and purest expression of love", no doubt finding confirmation of his feelings about ottoline in such lines as:

$$
\begin{aligned}
& \text { Love says of her: "How can a mortal thing } \\
& \text { Have purity and beauty such as hers?" } \\
& \text { Then looks again and to himself he swears } \\
& \text { A marvel she must be which God intends. } \\
& \text { Pearl-like, not to excess, her colouring, } \\
& \text { As suited to a lady's face, appears. } \\
& \text { She is the sum of nature's universe. } \\
& \text { To her perfection all of beauty tends. }
\end{aligned}
$$

For Russe?1, if not quite so certainiy for Ottoline, it was a time of erotic excitement but a1so of the profoundest inward change. "I always long to stretch out and grow, and there is room in you"--his "inspiration of life", as it is put in a letter of 11 October 1911 (215). Or, as he phrases his admiration in letter 128 , "all poetry and al1 imagination goes out to you so naturaliy--it all seems to belong to you."

${ }^{3}$ Dante Alighieri, La Vita Nuova (Poems of Youth), trans. Barbara Reynolds (Penguin, 1969), p.56. 
Clearly Russell, al ready well read in the poets, was submitting himself to the most powerful literary influence of a lifetime, through a woman who made it' real.

Yet no love on this plane is likely to survive there indefinitely, least of all Russell's for a married woman with loyalty to husband and child. The inevitably painful sequel revealed in the letters as the relationship sometimes subtly, sometimes dramatically changed cannot be followed here. Here we may comment briefly on the second paragraph of the letter quoted in full, a paragraph in which Russell sees clearly what it is he is about as a writer. He is composing, in spontaneous, telling instalments, a spiritual autobiography, a history of inner transformations vital to his serise of who he is. This literary form had its rise in England during the seventeenth-century religious controversies, bùt Russell hybridized spiritual autobiography with the letter yielding something not usually expected of the letter alone, though there is precedent in the letters of Cowper and Keats. Nevertheless the letter as spiritual autobiography--the epistolary spiritual autobiography--does not come fully into its own until Russell's amatory excitement prompted him to step up the letter's power to convey and examine this emotion in its religious guise. Certain that romantic love was akin to religious revelation, Russell set out more boldly than any previous writer to prove its renewal of his being, his rebirth through love of woman. This is the spiritual basis of all he says, and it was a prophetic gospel to be accepted and shared by her. "Oh if I could make you feel it as I feel it! If I could lead you forth from your spiritual cloister!", he writes at his most urgent on 24 March 1912 (402).

Frequently Ottoline was at a loss to know just how to respond to such ardent attention.

Further on in the letter quoted in full, Russell justifies his romanticism in the name of a secular religion. The reference to sarton Resartus is significant in this connection, since Thomas Carlyle was nothing if not prophetic in that book, an idealist telling the world to mend its ways, to see itself as a unity through poetic imagination. Sartor's character Herr Teufelsdröckh, whose life and opinions are given, is a classic instance of william James' "twice born soul", his social. teachings a product of a remade self. The dynamism of Teufelsdröckh's personality as Carlyle shapes it no doubt appealed to Russell, with the presence of fictional spiritual autobiography in Carlyle's book encouraging Russell to think of himself as emergent, not fixed nor finished as a person. This is at the heart of his letters to Ottoline. It is perhaps surprising that Russell, so given to the rigours of logical thinking, should have listened to a prophetic voice such as Carlyle's. Yet the constrictions of a life guided mainly by logical pursuits proved so unnatural as to require a dramatic shift to the opposite. Stimulated by ottoline, Russell reached beyond logic to romantic fulness of being, feel ing himself ready to become a prophet to his age as Carlyle had been early in the nineteenth century. Writing late in April 1912 (letter 428), Russell somewhat rashly says: "I ought to make myse If the prophet of the age, as Carlyle was to his age..." But he was not ready for such a mission. Still too dependent on literary models for his own writing and on the temporary spiritual inflation brought by 0ttoline, he had travails to pass through before the credible prophet finally emerged.

Carlyle is frequently mentioned in the letters, and Russell seems to have been lifted up on Carlyle's literary wings. It would be strange if he had not taken notice of Carlyle's love-letters to Jane Welsh, handsomely published in 1909. These lively, sometimes inspired letters, so revealing of Carlyle and of his gifted correspondent, might well have been a model for Russell's to 0ttoline, though we do not know that either of them possessed these volumes. Does not Carlyle's description of the purpose of letter-writing exactly fit Russell's as shown in the letters to ottoline? "It seems to me that the chief end of Letters is to exhibit to each a picture of the other's soul,--of all the hopes and fears that agitate us, the joys and sorrows and varied anxieties in which a heart'sfriend may be expected to sympathise...."4 The difference is in reversal of roles. Carlyle was intellectual mentor to Jane while Russell looked to 0ttoline for a like activation of his deepest self; yet he too hoped for "a picture of the other's soul", and certainly he repeatedly bared his to her.

In part Russell idolized 0ttoline; but also there was a mirroring function showing him to himself in change, important in any such transformation as that Russell was going through. When taken as far as it was, this mirroring began to disabuse Russell of the notion that a love religion alone could supply a new prophetic gospel. It induced a needed realism. While not impeding further amorous pursuits, mirroring certainly did teach Russell that love alone would not save the world. It is interesting that when in the 1960s Russell became the effective prophet of the anti-nuclear weapons campaign, the suppositions of a this time collective secular "love religion" were on the rise, though Russell can by no means be held solely responsible for this rise. He was not innocent of it either, having written to promote a liberalized sexua] morality, for example in Maxmiage and Morazs (1929). It would be valuable

4The Love Letters of Thomas Carlyle and Jane WeZsh, ed. Alexander Carlyle (London: John Lane, The Bodley Head, 1909), I, p.32 (Letter 11 , 26 Feb. 1822). Lady Ottoline gave Russell a copy of Carlyle's New Letters, published in 1904. 
to trace the possible connections. How many reformers since Russell have had to learn--as he did in the affair with ottoline--that, narrowly taken, love will not save the world?

I want here, however, to keep to the literary point, showing Russell's attention to other literature and his hope to write importantly himself. Russell was a natural autobiographer, sometimes impelled by sorrows almost too deep for words, at others by the joys of attained desires. Whichever it was, he often committed his feelings to paper first in letters--most powerfully in the letters to 0ttoline--then to the autobiography proper, which was begun in earnest in the 1930s at the suggestion of Sir Stanley Unwin. We should be aware, however, that an earlier attempt at autobiography had been made in the exci-tement of love for Ottoline. Russell wrote to her on 23 April 1912 (421) that in the past year an access of creative energy allowed him to draft an autobiography capturing the essence of his life. Two letters on, Russell is glad to hear that ottoline likes the autobiography which he plans to publish anonymously as by "Simon Styles"; but he is discouraged (letter 439) upon showing it in part to Mrs. Whitehead (his advisor and confidant, the wife of A.N. Whitehead), who found it "too egotistical"--a moral fault Russell reflects is due to a selfish state of mind he has lately been in. In the letter of 21 May (459) he has decided to turn the autobiography into a fictional conversation between an old and a young man, the old man commenting in the first person as the young man, his former self, grows up. This too clever device seems not to have satisfied him either. Russell in turn placed unfounded hopes in the dialogue called "Forstice" to satisfy his impulse to imaginative writing. What he did not fully realize was that the letters to ottoline themselves are the imaginative statements he wanted to make. The letters are his essential and most meaningful autobiography, never improved upon, except of course by the consecutive narration of autobiography proper. The letters are written in a clear hand (with occasional variations in handwriting showing emotional perturbation), are amazingly fluent, and seldom corrected. Russel] writes with an ease not given him in any other literary form, except perhaps the essay of which he was an acknowledged master.

How can letters about a real and present relationship be imaginative? They are so in a curious way--not merely as expressions of intense passion which Russell urges in the letter quoted. It is more than the reference to "flaming souls set on this little planet...", perhaps too purple a passage unless seen fully in the context of this and other letters. By "imaginative" he did not mean that he heightened feelings by writing them up, as he so affectingly had done in "A Free
Man's Worship", later questioned by him as to its too florid Miltonic style. In the broadest sense the imaginative quality of these letters is their fabrication of an ideal lover, 0ttoline, a transcendent woman, a Beatrice or Laura, of another world than this one yet more readily than they attainable here. The idealized 0ttoline with Russell's heroic love for her is an imaginative "creation" of the first order, but it shades off from its full glory into something more mundane as the interpersonal reality of the situation beyond these favoured two takes hold upon them. The letters' poignance is in their forced adjustment to reality with Russell discovering mixed feelings towards the real ottoline and, in her, an 0ttoline who, whether he likes it or not, has a life with other people not directed by his great need for affection and companionship. From early in 1912, passion aroused and briefly satisfied mingles noticeably with sharp disappointment and a sense of grievance against the idealized woman who shows him to himself as the turbulent but affectionate spirit he is. Self-knowledge is gained. This is the full autobiographical meaning of these letters--an unequalled record of the troubled lover's self-discovery in all its fluctuations of ardour and bitterness. Major and minor crises are weathered and many misunderstandings and reversais of feeling are overcome. To see this in all its array the full correspondence must be read, a requirement of Russell scholarship oniy a full edition could facilitate.

Selective editing of the letters' great bulk of words--repetitious sometimes but always with elements of new meaning in the expanding relational analysis--will have to be extremely skilful to bring out their real point: the desperate doomed effort to correct a loneliness at the core of Russell's being by allying it with Ottoline's different loneliness. The few paragraphs of telescoped impressions from the affair with Ottoline in Chapter VII of Volume I of Russell's Autobiography hardly do justice to the person he was as shown by the correspondence itself. Nor could any but the most carefully considered selection of the letters do this unless the editor had decided just what was happening to Russell psychologically in the period of transformation. To read even his side of the correspondence whole is to risk losing patience with detail and to risk going astray in the multitude of fascinating side issues in social and cultural history. Yet this is the only certainty of seeing its full autobiographical significance. There is in these letters a Russell still unknown and strangely ungrasped in the Autobiography by which he chose to be known. If Russell had worked over these letters in their completeness while writing the Autobiography, or if he had edited them himself, it is open to question whether he would have been able to go through with the project. The essence of this tormented, 
supremely gifted man is much richer, unsettlingly so, in the burgeoning letters to Ottoline than anywhere in the printed sources for his life. Russell had a way of tidying into neat parcels of words the past eras of his life; he was not a minutely examining self-reconstructor such as, for example, the nineteenth-century autobiographer Augustus J. C. Hare. Russell liked to make up his mind about the meaning of events and offer the briefest, pithiest statement of his conclusion. Yet the letters survived to be extracted in the 1930s, and they survive with few losses still, so we can assume that he was not afraid to have them seen and studied. Was this affair a folie à deux, a romantic delusion they shared unequally and then shed, or did Russell, the more ardent partner, really gain in self-knowledge and mastery, as the great religious autobiographers of earlier centuries say they did? Russell is no St. Augustine, but he is hardly less interesting or significant for the civilization to which he belongs.

We noted that the affair with Ottoline taught Russell humanity, convincing him of the loneliness and tragedy that clings to each life. To become too aware of this, however, may prompt dangerous cynicism. When war came in 1914 Russell was not a cynic but one of the few English intellectuals who had courage to speak publicly of the folly and pity of armed conflict. By then disappointment in Ottoline, and more in himself, showed that more than the simple power of love was needed to redeem loneliness and despair. Understanding too was necessary, with intel lect reinstated to examine autobiographically the pain exposed by too much passion, by the excessive exactions he made of her. In the letters Russe11 writes of his many mistakes with Ottoline and others and of his wish to do better in human relations. But the war cut short the potential development of this theme; Russell quickly became a public figure, mercifully perhaps no longer quite so alone with his contradictory private feelings. A strong beginning had nonetheless been made toward autobiography, which need only honestly present emotional complications, not theorize as to how they might be cleared up.

The paradox revealed by his transparent honesty about his mixed motives in love is everywhere apparent in the letters, a paradox Russel1 did not then or ever resolve. But his struggle against excessive passion, leading to overmuch praise and blame of Ottoline, did have a valuable result in allowing him to see that right in a relationship is never simply on one side, the common human error in love and war. Discouraging to Russell's unqualifying admirers though much in the letters to Ottoline may be, they do certainiy show a little appreciated strength of his: the acquired ability to see both sides of a relational difference of feeling and opinion. Whatever mistakes he compulsively makes and makes again, the Russell of the letters is tender and open to change for the better. He had genuinely decided to learn from her to the limit of his capacity, though finding much that he was forced to learn unexpected. By fearless probing and stock-taking of self--without an immediate view to publication--Russell moved in his being toward "wisdom" of the kind once associated with philosophers. Only a careful reading of the letters can instruct us about the cost at which this wisdom was bought. Having paid at the rate he did, it is a shame that after 1916 Russell did not write a reflective full-scale preliminary to Marriage and Morazs. The affair with ottoline never received the deep consideration it merited; Russell's wisdom gained from it consisting in generalizations about the sadness and impermanence at the core of life.

Writing letters to 0ttoline undoubtedly gave Russell impetus to self-study he would not otherwise have had. As he comments in letter 394, "We get something from letters that we should not get otherwise-the deeper things come out, and I think you say things you would hardly say in talk." If they are candid, searching and frequent enough, such personal letters result in more than casual self-analysis for the writer. He has a listener who comments, and 0ttoline was an excellent listener when her health permitted. In this, Russell's prime crisis period, the letters confer benefit he could not fully measure. Though altered patterns of communication have rendered letter-writing less an art for us, we should see that for him the letter, leading to epistolary autobiography, was an inescapable literary form that arose so naturally he scarcely realized its importance. Adjusted one way, toward the essay, the letter could argue; adjusted toward poetry it could evoke feelings to move the reader to empathetic understanding. Russell's prose instrument is precisely adjustable between these functions. We have not yet gauged his full achievement in this and correspondences with other people, men and women, but it is not a complete exaggeration to say with Rosemary Dinnage that Russel 1 "may yet be remembered for his love letters rather than his works on logic. "If so, it will be because they trace a pattern of human growth in which we all have a vital interest when introduced to it by a writer of Russell's calibre. Such large patterns of meaning are, after all, what 7 iterature exists to display. The letters to ottoline will be read for many different reasons; but whatever is looked for in them, let us not lose sight of their extraordinary quality simply as letters, and of their incomparable worth as autobiography.

Department of Engtish

Andrew Brink McMaster University

${ }^{5}$ Rosemary Dinnage, Review of Clark's Life of Bertrand Russell, Times Literary Supplement, 31 oct. 1975, p.1283. 